\title{
Trichinella spiralis in a South American sea lion (Otaria flavescens) from Patagonia, Argentina
}

\author{
M. I. Pasqualetti ${ }^{1,2} \cdot$ F. A. Fariña ${ }^{1,2}$ - S. J. Krivokapich ${ }^{3} \cdot$ G. M. Gatti ${ }^{3}$ - G. A. Daneri ${ }^{4}$ - E. A. Varela ${ }^{4}$ - S. Lucero $^{4}$ • \\ M. E. Ercole ${ }^{1} \cdot$ C. Bessi ${ }^{1}$ - M. Winter ${ }^{5,6}$ - M. M. Ribicich ${ }^{1,2}$
}

Received: 5 July 2018 / Accepted: 7 October 2018

(C) Springer-Verlag GmbH Germany, part of Springer Nature 2018

\begin{abstract}
Trichinella spp. from a sylvatic cycle has been found in several animal species such as pumas (Puma concolor), armadillos (Chaetophractus villosus), rats (Rattus norvegicus), and wild boars (Sus scrofa) in Argentina. Moreover, Trichinella infection has been detected in a wide range of marine mammals around the world, including polar bears (Ursus maritimus) and walruses (Odobenus rosmarus). Until the present time, Trichinella spp. infection has not been detected in marine mammals of South America. Samples from four South American sea lions (Otaria flavescens) found dead in Rio Negro, Argentina, were analyzed by artificial digestion, and in the case of one animal, Trichinella larvae were identified at the species level by nested multiplex PCR as Trichinella spiralis. This is the first report of a Trichinella species infecting marine mammals from South America.
\end{abstract}

Keywords Trichinella spiralis $\cdot$ Trichinella $\cdot$ Otaria flavescens $\cdot$ South American sea lion $\cdot$ Marine mammals

\section{Introduction}

Trichinellosis is a worldwide food-borne zoonotic disease caused mainly by the consumption of raw or uncooked meat from different animal species infected with parasites belonging to the genus Trichinella (Gottstein et al. 2009). These nematodes are a complex that encompasses nine species and three genotypes with a broad geographic range that can infect mammals, birds, and reptiles (Pozio 2016). These parasites complete their life cycle in a single host. Although Trichinella has no free-living stage, the environmental temperature and moisture influence the circulation of these nematodes in nature (Pozio 2016).

Section Editor: Herbert Auer

M. I. Pasqualetti

1 Universidad de Buenos Aires, Facultad de Ciencias Veterinarias, Cátedra de Parasitología y Enfermedades Parasitarias, Av. Chorroarín 280, C1427CWO CABA, Argentina

2 CONICET - Universidad de Buenos Aires, Instituto de Investigaciones en Producción Animal (INPA), Av. Chorroarín 280, C1427CWO Buenos Aires, Argentina

3 ANLIS, Dr. Carlos G. Malbrán, Buenos Aires, Argentina
In Argentina, Trichinella spp. from a sylvatic cycle have been found in several animal species such as pumas (Puma concolor), armadillos (Chaetophractus villosus), rats (Rattus norvegicus), and wild boars (Sus scrofa) (Ribicich et al. 2010; Pasqualetti et al. 2014). The first human case of trichinellosis in Argentina was reported in 1898, and it is currently accepted as an endemic disease, mainly transmitted by the consumption of raw or undercooked pork (Fariña et al. 2017). During the year 2014, 1120 human cases were notified by the Health Surveillance National System; provinces of Buenos Aires (58.75\%), Córdoba (17.58\%), Corrientes (7.05\%), and Santa $\mathrm{Fe}(5.26 \%)$ reached the highest records. At present, only T. spiralis, T. patagoniensis, T. pseudospiralis, and T. britovi

4 Laboratorio de Sistemática, Anatomía y Bioecología de Mamíferos Marinos, Division Mastozoología, Museo Argentino de Ciencias Naturales, "Bernardino Rivadavia"- CONICET, Av. Angel Gallardo 470, C1405DJR CABA, Argentina

5 Universidad Nacional de Río Negro-Sede Atlántica, Viedma, Río Negro, Argentina

6 Centro de Investigación y Transferencia Río Negro, Viedma, Río Negro, Argentina 
have been recorded to have infected animals in Argentina (Fariña et al. 2017, Krivokapich et al. 2015a, 2015b).

Trichinella infection has been detected in a wide range of marine mammals around the world. It was found in polar bears (Ursus maritimus) and in walruses (Odobenus rosmarus) (Forbes 2000), and it has also been documented in seals (Isomursu and Kunnasranta 2011). Consumption of infected meat from walruses (Odobenus rosmarus) and polar bears (Ursus maritimus) is considered as a significant health risk to native people of the Arctic areas (Kapel et al. 2003).

The most abundant otariid on the Argentine marine coast is the South American sea lion Otaria flavescens, which is widely distributed from Mar del Plata, in Buenos Aires $\left(38^{\circ} 12^{\prime} \mathrm{S}\right.$, $\left.57^{\circ} 33^{\prime} \mathrm{W}\right)$ to Tierra del Fuego $\left(52^{\circ} 27^{\prime} \mathrm{S}, 69^{\circ} 25^{\prime} \mathrm{W}\right)$ in around 100 rookeries. Since the dramatic reduction of the Southern sea lion population on the Argentine coast between the 1930s and 1950s, Executive Order no. 1.216 was enacted to protect them. Although the population of $O$. flavescens is currently increasing, it has not yet reached its original level (Bustos et al. 2012).

Until the present time, there were no records of Trichinella infection in marine mammals of South America. This is the first finding of a Trichinella species in the South American sea lion (Otaria flavescens), in Argentina.

\section{Materials and methods}

Four South American sea lions were found dead in the rookeries of Caleta de los Loros (Lat. $41^{\circ} 00^{\prime} \mathrm{S}$; $64^{\circ} 12^{\prime}$ $\mathrm{W} ; n=1$ ), Promontorio Belén (Lat. $41^{\circ} 09^{\prime} \mathrm{S}$; Long. $63^{\circ} 48^{\prime}$ $\mathrm{O} ; n=1$ ) and Punta Bermeja (Lat. $41^{\circ} 09^{\prime} \mathrm{S}$; Long. $63^{\circ} 09^{\prime}$ $\mathrm{O} ; n=2$ ) in Rio Negro, Argentina. This location is a Natural Protected Area dependent on the Consejo de Ecología y Medio Ambiente (CODEMA) in Río Negro (Fig.1). These sea lion colonies are located within Natural Protected Areas administered by the Secretaría de Ambiente y Desarrollo Sustentable (SAyDS) of Río Negro Province and represent important reservoir of juveniles, with small breeding areas in constant growth. The colonies are permanent and experience seasonal variation in number of individuals throughout the year (Bustos et al. 2012).

Muscle samples were taken from the tongue and diaphragm and were stored at $4{ }^{\circ} \mathrm{C}$ until examination at the Parasitology Laboratory of the Facultad de Ciencias Veterinarias, Universidad de Buenos Aires. The total muscle samples from each animal were analyzed by artificial digestion according to Gamble et al. (2000) to determine the presence of Trichinella larvae. The weight of the samples ranged from 4.8 to $80 \mathrm{~g}$.

The larvae recovered by artificial digestion from the animals' muscles were morphologically identified using an inverted microscope, washed in PBS, and preserved in absolute ethanol until molecular species identification.

DNA from individual larvae of Trichinella was obtained following the protocol described by Krivokapich et al. (2006). Identification at the species level was made by nested multiplex polymerase chain reaction (nested multiplex PCR) based on nuclear ribosomal DNA sequences, using six pair of primers (Table 1), according to Zarlenga et al. (1999).

\section{Results}

Trichinella spp. larvae were found in one of the four South American sea lions. The animal that tested positive was from Caleta de los Loros rookery, while the others that tested negative were from Promontorio Belén and Punta Bermeja (Table 2).

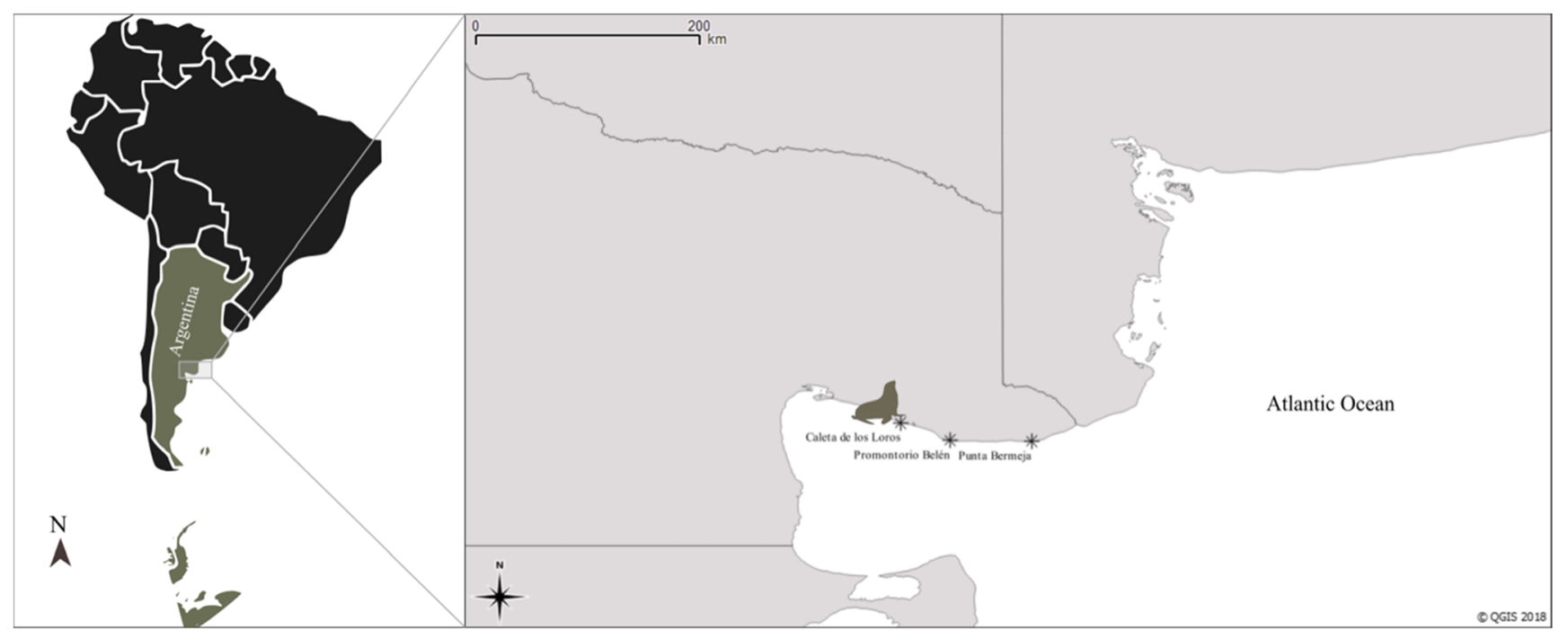

Fig. 1 Locations where South American Sea lions were found. They are shown by an asterisk in Rio Negro Province, Argentina 
Table 1 Nested multiplex PCR primers, previously published by Zarlenga et al. 1999, using in the molecular identification at the species level of the Trichinella isolate from Otaria flavescens

\begin{tabular}{|c|c|c|}
\hline $\begin{array}{l}\text { Primer } \\
\text { pair }^{\mathrm{a}}\end{array}$ & Sequences & \\
\hline $\mathrm{Ne}$ & $5^{\prime}$ TCTTGGTGGTAGTAGC $3^{\prime}$ & 5' GCGATTGAGTTGAACGC 3' \\
\hline $\mathrm{Ni}$ & $\begin{array}{l}\text { 5' AAAGGAATTCAAGTCGTAACAAGGTT } \\
\text { TCCGTAGG 3' }\end{array}$ & $\begin{array}{l}\text { 5' AAATCTAGATTAGTTTCTTT } \\
\text { TCCTCCGC 3' }\end{array}$ \\
\hline I & 5' GTTCCATGTGAACAGCAGT 3' & 5' CGAAAACATACGACAACTGC 3' \\
\hline II & 5' GCTACATCCTTTTGATCTGTT 3' & $\begin{array}{l}5^{\prime} \text { AGACACAATATCAACCACAG } \\
\text { TACA } 3^{\prime}\end{array}$ \\
\hline III & 5' GCGGAAGGATCATTATCGTGTA 3' & $\begin{array}{l}5^{\prime} \text { TGGATTACAAAGAAAACCAT } \\
\text { CACT } 3^{\prime}\end{array}$ \\
\hline IV & 5' GTGAGCGTAATAAAGGTGCAG 3' & 5' TTCATCACACATCTTCCACTA 3' \\
\hline $\mathrm{V}$ & 5' CAATTGAAAACCGCTTAGCGTGTTT 3' & 5' TGATCTGAGGTCGACATTTCC 3' \\
\hline
\end{tabular}

${ }^{\mathrm{a}} \mathrm{Ne}$ and Ni: primer pairs employed in the nested PCR. Primer pairs I-V: used in the multiplex PCR
Based on their morphology, the recovered larvae were suggestive of Trichinella spp. Trichinella larvae generated a fragment of $173 \mathrm{bp}$ corresponding to T. spiralis expansion segment V (ESV) region of the ribosomal DNA (Fig. 2).

\section{Discussion}

The isolation of T. spiralis from a South American sea lion shows that this marine mammal can be a host of this Trichinella species.

The molecular identification by nested multiplex PCR shows that the isolate analyzed belonged to $T$. spiralis. The lower intensity of the PCR products on agarose gel electrophoresis of the isolate from sea lion compared with positive control could be attributed to the difference in the preservation of the samples (Fig. 2).

$O$. flavescens has a diverse diet, which corroborates its generalist and opportunistic feeding behavior (Bustos et al. 2012). They feed on a diverse range of fish and cephalopod species. Moreover, adult males can prey on South American Fur Seals (Arctocephalus australis) pups and adult females (Reeves et al. 1992).

Sea lions are able to kill young Southern Elephant Seals (Mirounga leonine) as it was recorded in the Malvinas/ Falkland Islands. Although they can prey on several species of penguins, the importance of these animals in the diet is unknown (Cardenas Alayza et al. 2016).

The geographical distribution of South American sea lions ranges from Torres in southern Brazil to Cape Horn in the extreme south of the Atlantic coastline, and from Cape Horn to Zorritos in northern Peru, on the Pacific (Cappozzo and Rosas 1991; Reyes et al. 1999). Genetic studies suggested that one population of South American sea lions extended through Uruguay, continental Argentina, and the Malvinas/Falkland Islands (Szapkievich et al. 1999).

Contamination of the environment by carcasses or by spread of scraps and offal from animals is important for Trichinella spp. infection in free-living animals (Gottstein et al. 2009).

Currently, most reported occurrences of Trichinella in marine mammals have been from Arctic areas. Odoevskaya and Spiridonov 2014 found representatives of the Artic complex (T. nativa-Trichinella sp. T6) in a seal from Chukotka, Russia. Moreover, it was shown that walruses are infected more frequently than bearded seals, ringed seals, unidentified seals, and Beluga whales. Until now, the only confirmed case of infection in cetaceans is the Beluga whale from Alaska (Forbes 2000). Based on experimental studies, a number of possible mechanisms have been proposed to explain the presence of Trichinella in marine animals. Seals and whales are probably infected through exposure to infected carcasses, by

Table 2 Data of location, sex, relative age, muscle sample, artificial digestion, and PCR of four South American sea lions from Patagonia, Argentina

\begin{tabular}{|c|c|c|c|c|c|c|c|}
\hline Animal no. & Locality & Sex & Relative age & $\begin{array}{l}\text { Muscle } \\
\text { sample }\end{array}$ & Grams & $\begin{array}{l}\text { Artificial } \\
\text { digestion }\end{array}$ & Multiplex PCR \\
\hline 1 & $\begin{array}{l}\text { Caleta de los Loros } \\
\quad\left(\text { Lat. } 41^{\circ} 00^{\prime} \mathrm{S} ; 64^{\circ} 12^{\prime} \mathrm{W}\right)\end{array}$ & Female & Young & Diaphragm & 80 & 3 larvae & Trichinella spiralis \\
\hline 2 & $\begin{array}{l}\text { Promontorio Belen } \\
\quad \text { (Lat. } 41^{\circ} 09^{\prime} \mathrm{S} \text {; Long. } 63^{\circ} 48^{\prime} \mathrm{O} \text { ) }\end{array}$ & Male & Subadult & Tongue & 15.5 & - & - \\
\hline 3 & $\begin{array}{l}\text { Punta Bermeja } \\
\left.\quad \text { (Lat. } 41^{\circ} 09^{\prime} \mathrm{S} \text {; Long. } 63^{\circ} 09^{\prime} \mathrm{O}\right)\end{array}$ & Female & Adult & Diaphragm & 4.8 & - & - \\
\hline 4 & $\begin{array}{l}\text { Punta Bermeja } \\
\left.\quad \text { (Lat. } 41^{\circ} 09^{\prime} \mathrm{S} \text {; Long. } 63^{\circ} 09^{\prime} \mathrm{O}\right)\end{array}$ & Female & Young & Tongue & 5 & - & - \\
\hline
\end{tabular}




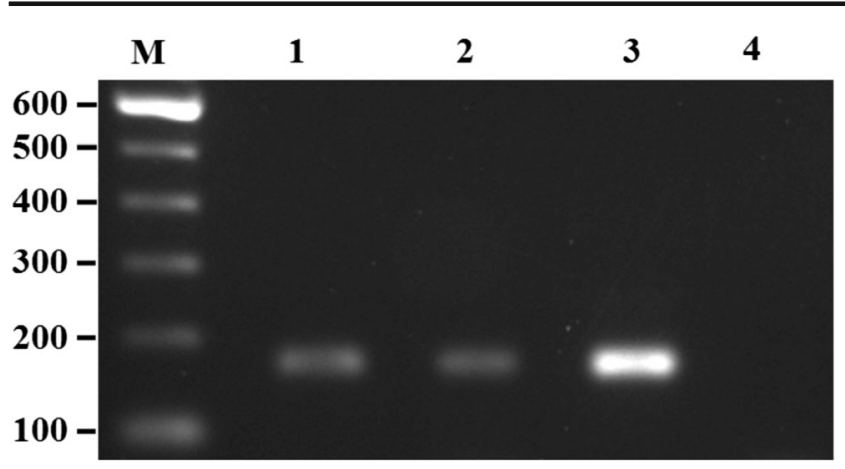

Fig. 2 Molecular identification at the species level. Lanes 1 and 2 show individual larvae of Trichinella found in a South American sea lion from Patagonia, Argentina; lane 3 shows individual larva from a reference strain of $T$. spiralis (code ISS643); lane 4 shows negative control. Lane M shows 100-bp DNA ladder (Invitrogen)

scavenging or by consuming infected amphipods or fish. The inefficiency of this mechanism could explain the low prevalence of Trichinella in seals and whales (Forbes 2000).

Goździk et al. (2017) recorded Trichinella coinfection with T. spiralis and T. nativa in a northern sea lion (Eumetopias jubatus) from the northeastern region of Russia, Chukotka Peninsula, in the Far Eastern Federal District. Similarly to Otaria flavescens, Eumetopias jubatus is an opportunistic marine predator, feeding mainly on fish.

This is the first report of a Trichinella species infecting marine mammals from South America. The inclusion of Otaria flavescens in the wide range of Trichinella hosts adds new questions to the epidemiology of Trichinella in marine animals. However, further epidemiological and molecular studies are needed to analyze the role of marine animals in the sylvatic cycle of Trichinella spp.

Acknowledgments We thank the Secretaría de Medio Ambiente y Desarrollo Sustentable (SAyDS) of Río Negro Province for giving us permission to get sample from the rookeries.

Funding This work was supported by Universidad de Buenos Aires, Secretaria de Ciencia y Técnica Subsidio UBACyT20020130100336BA and Ministerio de Ciencia y Tecnología, FONCyT Subsidio PICT-2015-2350.

\section{Compliance with ethical standards}

Conflict of interest The authors declare that they have no conflict of interest.

\section{References}

Bustos RL, Daneri GA, Volpedo AV, Harrington A, Varela EA (2012) The diet of the South American sea lion (Otaria flavescens) at Río Negro, Patagonia, Argentina, during the winter-spring period. Iheringia Sér Zool 102(4):394-400

Cappozzo HL, Rosas FCW (1991) Leon Marino Sudamericano, Otaria flavescens (Shaw, 1800). In Cappozzo, HL and Junin, M (eds.). California: PNUMA (Programa de Naciones Unidas para el Medio Ambiente), pp. 166-170
Cardenas Alayza S, Crespo EA, Oliveira L (2016) Otaria byronia, South American Sea Lion. http://www.iucnredlist.org/details/41665/0 (accessed 6 June 2018)

Fariña F, Pasqualetti M, Ilgová J, Cardillo N, Ercole M, Aronowicz T, Krivokapich S, Kašný M, Ribicich M (2017) Evaluation of the infectivity and the persistence of Trichinella patagoniensis in muscle tissue of decomposing Guinea pig (Cavia porcellus). Parasitol Res 116(1):371-375

Forbes LB (2000) The occurrence and ecology of Trichinella in marine mammals. Vet Parasitol 93(3-4):321-334

Gamble HR, Bessonov AS, Cuperlovic K, Gajadhar AA, Van Knapen F, Noeckler K, Schenone H, Zhu X (2000) International commission on trichinellosis: recommendations on methods for the control of Trichinella in domestic and wild animals intended for human consumption. Vet Parasitol 93:393-408

Gottstein B, Pozio E, Nöckler K (2009) Epidemiology, diagnosis, treatment, and control of trichinellosis. Clin Microbiol Rev 22(1):127-145

Goździk K, Odoevskaya IM, Movsesyan SO, Cabaj W (2017) Molecular identification of Trichinella isolates from wildlife animals of the Russian Arctic territories. Helminthologia 54(1):11-16

Isomursu M, Kunnasranta M (2011) Trichinella nativa in grey seal Halichoerus grypus: spill-over from a highly endemic terrestrial ecosystem. J Parasitol 97(4):735-736

Kapel CMO, Møller LN, Forbes L, Gajadhar A (2003) Experimental Trichinella infection in seals. Int J Parasitol 33(13):1463-1470

Krivokapich SJ, Molina V, Bergagna HFJ, Guarnera EA (2006) Epidemiological survey of Trichinella infection in domestic, synanthropic and sylvatic animals from Argentina. J Helminthol 80(3):267-269

Krivokapich SJ, Gatti GM, González-Prous CL, Degese MF, Arbusti PA, Ayesa GE, Vera Bello G, Salomon C (2015a) Detección de Trichinella britovi en un producto porcino involucrado en un presunto brote de trichinellosis en Mendoza, Argentina. In: APA (ed) Libro de resúmenes del VII Congreso Argentino de Parasitología, 1st edn. Asociación Argentina de Parasitología, Buenos Aires, p 34

Krivokapich SJ, Prous CLG, Gatti GM, Saldía L (2015b) First finding of Trichinella pseudospiralis in the Neotropical region. Vet Parasitol 208(3-4):268-271

Odoevskaya IM, Spiridonov SE (2014) Molecular taxonomic study of Trichinella spp. from mammals of Russian Arctic and subarctic areas. Czech Polar Rep 4(1):40-46

Pasqualetti M, Fariña F, Falzoni E, Cardillo N, Aronowicz T, Krivokapich S, Rosa A, Ribicich M (2014) Susceptibility of chickens (Gallus gallus domesticus) to Trichinella patagoniensis. Vet Parasitol 205(1-2):397-400

Pozio E (2016) Adaptation of Trichinella spp. for survival in cold climates. Food Water Parasitol 4:4-12

Reeves RR, Stewart BS, Leatherwood S (1992) Fur seals and sea lions, family: Otariidae. In: Reeves RR (ed) The Sierra Club handbook of seals and sirenians, vol 169. Sierra Club Books, San Francisco, pp 50-129

Reyes LM, Crespo EA, Szapkievich V (1999) Distribution and population size of the southern sea lion (Otaria flavescens) in central and southern Chubut, Patagonia, Argentina. Mar Mammal Sci 15(2): 478-493

Ribicich M, Gamble HR, Bolpe J, Scialfa E, Krivokapich S, Cardillo N, Betti A, Cambiaggi Holzmann M, Pasqualetti M, Fariña F, Rosa A (2010) Trichinella infection in wild animals from endemic regions of Argentina. Parasitol Res 107(2):377-380

Szapkievich VB, Cappozzo HL, Crespo EA, Bernabeu RO, Comas C, Mudry MD (1999) Genetic relatedness in two Southern Sea lion (Otaria flovescens) rookeries in the southwestern Atlantic. Z Säugetierkunde 64(4):246-250

Zarlenga DS, Chute MB, MartinA KCM (1999) A multiplex PCR for unequivocal differentiation of all encapsulated and non-encapsulated genotypes of Trichinella. Int J Parasitol 29(11):1859-1867 